$\mathrm{Oz}$

Volume 29

Article 7

$1-1-2007$

\title{
Top Hats
}

Larry Bowne

Follow this and additional works at: https://newprairiepress.org/oz

(c) (i) $\Theta \Theta$

This work is licensed under a Creative Commons Attribution-Noncommercial-No Derivative Works 4.0 License.

\section{Recommended Citation}

Bowne, Larry (2007) "Top Hats," Oz: Vol. 29. https://doi.org/10.4148/2378-5853.1447

This Article is brought to you for free and open access by New Prairie Press. It has been accepted for inclusion in Oz by an authorized administrator of New Prairie Press. For more information, please contact cads@k-state.edu. 


\section{Top Hats}

Larry Bowne

"It might be good to open our eyes and see."

-Thomas Merton

The photographs on the following pages were taken by students enrolled in the seminar "Some Manhattan Apartments," which I taught in the spring of 2007 in the Department of Architecture at Kansas State University in Manhattan, Kansas. The course investigated a local building type, the half-roofed, walk-up triplex apartment building (Figure 1).

Manhattan, a small college town with fewer than fifty thousand permanent residents, sits at the confluence of the Big Blue and Kansas Rivers. The Flint Hills roll in all directions through and out of town, and one need not travel far to be surrounded by the tall grasses of the Konza prairie.

Manhattan, famously "the Little Apple," has a tenuous hold on its own identity Founded by abolitionists who first named the settlement "Boston," Manhattan changed its name shortly after its founding to appeal to some Ohioan migrants, who decided to remain when their steamboat ran aground in the Kansas River, but who preferred to settle in a place with a more prestigious eponym.

The Jeffersonian grid-that great occupation of the continent by Enlightenment thinking long before actual Anglo bodies arrived to settle it-organizes Manhattan. In the older center of the town, arterials at half-mile intervals all of which bisect each other at ninety degree angles These streets are lined, more or less, by single-family homes, many of them low-slung bungalows in the prairie style

In their siting and context, the apartment buildings stand out. These are triple-decker multi-unit rental buildings interspersed in a community of owner-occupied homes. The rental buildings, built from the 1960s through the 1980 s, are located in neighborhoods which achieved their abiding character decades earlier. The bulk and heft of these apartment blocks contrast sharply with their neighbors.

The apartment buildings are strikingly peculiar, indeed a sort of morphological anomaly. Like the tutu-clad hippos in Walt Disney's Fantasia, these units are bulky but insistently purport not to be. In massing, roofline, siding, and detailing, they refer to the surrounding owner-occupied singlefamily detached houses. They achieve their stealthy quality by two primary sectional moves. First, their builders push the lowest occupied floor deep into the ground, with low windows at the building perimeter just above the height of the mudsill. Inside, these windows serve as clerestories to the apartments. They are sized just large enough to provide the legal light and air required by local building codes. Second, they skirt the uppermost dwelling floor with a sort of "roof" so that from the street the building appears to be a single-family house with a Mansard roof.

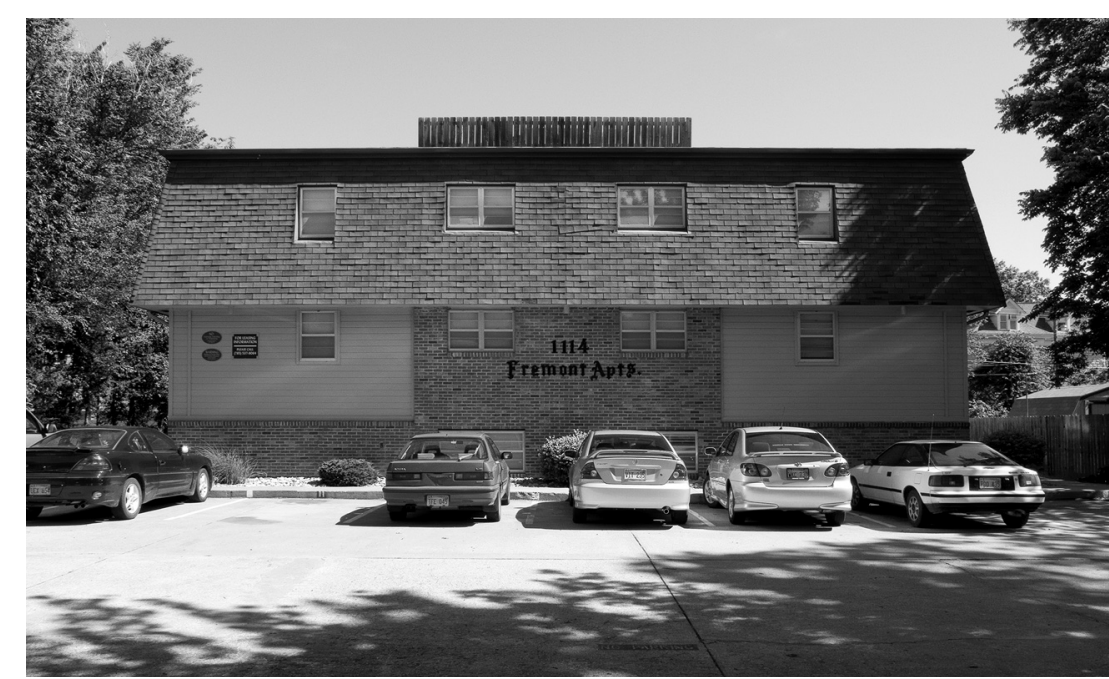

Figure 1. 1114 Fairchild Avenue, Manhattan, Kansas.

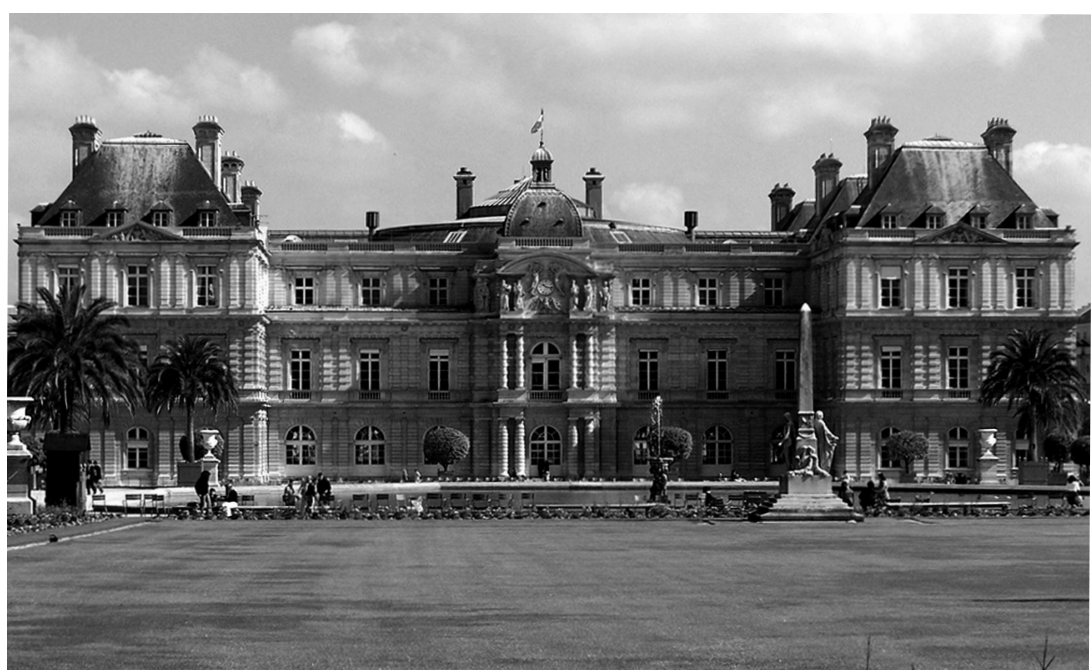

Figure 2. Palais du Luxembourg, Paris.

The roof dominates the type and is its most distinguishing feature. It covers nearly half of the vertical wall surface, and often projects from the plane of the wall several feet. The roof is inevitably clad differently than the wall "beneath" it, even when the roof is in the same plane as the wall and the only distinction between the two is a narrow outrigged soffit. The Mansard itself, popularized by the French architect Francois Mansart, has a rich but curious history in architecture. The Mansard first emerged in Seventeenth-century Paris as a device to lower property taxes, which at the time 
were established by calculating usable space located below the line of the eave. Functionally, the steeply sloped roof makes for a fully operational attic, serves to integrate the upper and lower masses of the structure, and lessens the visual heft of the volume in its surroundings (Figure 2).

After widespread application throughout France in the latter half of the seventeenth century, the steeply-sloped hip fell out of favor. Under the Second Empire of Napoleon III, the style came once again into fashion; it can still be seen today throughout Hausmann's Paris. In the United States, the Mansard roof was used during the nineteenth century in municipal and multi-story residential buildings; in our contemporary suburban era, the Mansard is perhaps best known as the profile of the prototypical McDonald's franchise.

In the Manhattan apartments under study here, the roof rarely functions as a roof at all. The actual roof-the membrane that defends against the torrents of rain and snow and protects against the harsh Kansas sun-sits above the Mansard, often a flat grave roof or a hip slung as shallow as necessary to shed water. Constructionally, then, the Mansard on these buildings is a wall (typically fabricated out of dimensional lumber) clad in roofing material. It says "roof" but in reality it is part of the vertical rather than horizontal assembly. Drainage discloses the hoax: gutters line the top rather than lower edges of the Mansard and leaders and downspouts often follow the outward edge of the false roof or, in more authentic cases, simply run plumb down the vertical surface, piercing the Mansard as they run to the ground.

This mock Mansard is often punctuated by dormers, balconies, and elaborate double-height entries. The dormer, however, is hardly a dormer often it is a sash window identical to one in the "wall" immediately beneath the "roof." In the finer examples of the type, the balconies alternately mimic the adjacent slope or offer a whimsical contrast. The greatest flourish, how ever, occurs at the entry. Typically, the entry has its own roof, skinned in the same veneer as the Mansard, often with a round, octagonal or otherwise exceptional window over the (usually brightly painted) front door. This smal window illuminates the stairwell that exists just inside the front door. A pair of sconces frames the entry. These are domestic fixtures, unsuitable for their location and function if their use is understood to be to illuminate the path to one's home. But if they are seen to be akin to the roof as a gesture towards the domestic, indeed towards a rather particularly elegant version of the private home, then they succeed perfectly.

A question arises: why look at these buildings at all? Do these apartments have aesthetic merit of any sort? In their siting, formal disposition, and materiality, they are utterly banal, a bane or blight on the local streetscape. They sit back from the street, aloof from the sidewalk, surrounded by a skirt of asphalt-paved parking. The structures increase the crowding of a neighborhood without creating the comportment and engagement that an urbane density might provide. If they make any exterior address, it is through projecting cantilevered balconies (often in dialogue with the roofline), not porches. Formally, these buildings are a hypocrisy, purporting toward one thing (the scale of the single-family house) while manifesting quite another: maximum rental return for (typically absentee) landlords. Materially, they are clad in the tawdriest of veneers: gravel-impregnated tar shingles, aluminum siding, beadboard panels, "faux" used brick.

And yet in their very oddness, their need to distinguish themselves from their neighbors, the units often evince an aspirational quality perhaps bes seen in their names: The Regency, The Ponderosa, The Cheverly, and the like. With a naivete that even an aesthete might enjoy, they use the simplest means to express their ambitions: balconies that recapitulate the roo profile, entries scaled not to the building but to the street beyond, plywood sconces in the shape of the university mascot, "Willie the Wildcat." The photographs isolate these bits of quotidian marvel, demonstrating that even when builders confine themselves to a palette of materials and artifacts derived entirely from the local hardware store, aesthetic delight may yet occur.

Here, one may first think of Susan Sontag's definition of Camp, a sensibility which delights in the ironic appreciation of exaggeration, artifice, and playfulness. In architectural terms, a Camp aesthetic focuses on distortions of scale, a jarring juxtaposition of artifacts from various eras, a love of colorful scintillating surfaces, and the like. In the popular vernacular, Camp characterizes the great roadside architecture of Route 66 and beyond: the donut shop topped by a giant plaster torus or the hot dog vendor taking orders from inside his lacquered fiberglass depiction of mustard, wiener and bun. In its more luxuriant manifestations, Camp distinguishes the great hotels of Miami Beach, from Morris Lapidus to Phillipe Starck, or defines the regal moderne of the hillside villas in Beverly Hills' Trousdale Estates.

It is no accident that the examples above tend to be from historic resort locales: Camp is fantastic. In Los Angeles, much of the landscape can be seen as variations on the theme of Camp. Even in the endless plain of sprawl, far from the beaches and hills that more readily perpetuate the Southern California mythos, developers have transformed the stucco-clad boxes of pipe columns and wood studs into a personal phantasm. The otherwise banal apartment buildings feature flourishes that have attracted architectural critics and visual artists alike. At the height of the Pop era, when Robert Venturi was trying to discern something about environmental aesthetics in the Nevada desert, the British historian Reynar Banham in Los Angeles: The Architecture of Four Ecologies popularized a term for the type, "Dingbats." The photographer, painter and graphic artist Ed Ruscha exten- 
sively documented the type in print and graphite, prominently featuring the Dingbat in his "Some Los Angeles Apartments." David Hockney painted them, and the graphic designer Clive Piercy compiled his photographs of them in the monograph Pretty Vacant: The Los Angeles Dingbat Observed.

Their studies of the Dingbat inspired our own. Students in the class, after Banham's example, came to call the Manhattan type the "Top Hat" not solely for its prominent faux Mansard but for its affectations towards elegance.

Sontag argues in the twenty-forth of her "Notes on "Camp" that not all tawdry aspirational artifacts can attain the vaunted status of Camp: "When something is just bad (rather than Camp), it's often because it is too mediocre in its ambition. The artist hasn't attempted to do anything really outlandish. ('It's too much,' 'It's too fantastic,' It's not to be believed, are standard phrases of Camp enthusiasm.)"2 I suggest that the Top Hats fail as Camp, largely because they are not bad enough, neither overly overweening nor excessive in sufficient degree to reach a level of disgracefully compelling failure (or, as it were, success). So if these buildings are a visual blight, a manifestation of raw developer greed, not even bad enough to be Camp, why look at all? What possible merit might ensue from architects looking at something so obviously "bad"?

In her essay "The Gehry Phenomenon, ing of how an architect might gain inspiration from a passionate embrace of the commonplace, which she describes in the work of the architect Frank Gehry as "topical thinking." Topical thought, unlike technical or theoretical thinking, concerns itself with the shared and "is based in common opinion, common law, local history, received customs, and language." Burns cites Gehry's transformation of the stucco Dingbat, what the architect calls the "dumb box," into a local icon. She specifically refers to the Danziger Studio-Residence (1964), but Gehry's entire body of work over the last four decades-particularly his manipulations of common materials such as wood studs, plywood, sheet metals, chain link fencing, and the like-can be seen as deployments of undervalued elements, components and conditions in the service of architecture-as-art. Burns notes that Gehry's work might resolve the Modernist-Postmodernist arguments raging in Ivy League studios at the time of her writing (the late 1980s): the architecture of Frank Gehry proves that neither abstraction nor figuration inherently results in an architecture of meaning, and that quotation and reference in contemporary work need not be exclusively to historic precedent. In other words, the common everyday built environment can inspire. Gehry connects that which is happening outside himself to his own work, a connection Burns considers a "poetic...descent to 'get to the bottom of things."' The passage is worth quoting at length:

Plato began the great dialogue, The Republic, with the word katabasis, which means a way down... The theme is similar in his parable of the cave after the ascent to the light from the darkness of the cave, the philosopher is told, "Down you must go," back to the world of the shadows, which is the common source for any insight. In returning to the commonplace and descending to fundamental conditions, the figure moving up and down is the scholar who joins different realms together in writing, speaking, and other forms of public rhetoric, including architecture. ${ }^{5}$

So some instructional merit might come out of looking at the regiona vernacular, some insight into form or volume or space. For an emerging architect, such training in the eye and mind are useful skills on their own. Observations of the real can become footings on which to construct imagined worlds.

I propose that we consider a more existential reason as well. I propose we look at the Top Hats because they are here, and we are here, and it behooves a citizen to cast his gaze about his terrain and observe. Thomas Merton argued that you have to be who you are; I choose to see his assertion and raise it: you have to be where you are too. Being where you are involves not blind acceptance to the place you find yourself, but it should not entail ignorance of the specificities of that location, either.

Here we can be guided by the exquisite example of Ed Ruscha and his likeminded cohorts. Beginning with his first drive to Los Angeles in the early 1960s, Ruscha turned his lens towards the overlooked detritus of the American roadside: the Standard gasoline station, the carwash, the electric sign flickering on the distant horizon. In a series of self-published books (Various Small Fires and Milk in 1964, Thirtyfour Parking Lots in 1967, etc.), Ruscha documents coolly and with seeming objectivity the commonplace objects of our quotidian experience. The artist offers a dispassionate, discursive description of contemporary environments, neither critiquing nor praising the thing described. Of course, the work often seems ridiculous (the small fires are rather small, for instance), and a bit of wry irony undermines the affected detachment.

Regardless, the observations are made and the work is offered for our consideration and, ultimately, judgment. Or perhaps not. For whatever our verdict on Ruscha's palm trees, his swimming pools or his Real Estate Opportunities-whether, that is, we damn their emptiness or revel in their insistent presence-such positions are at best penultimate. Something else is yet to come.

Ruscha undeniably crafts his artifacts: each shot is composed and cropped and pasted up, each book a nearly cinematic feat of visual editing and graphic design. Most likely, we reserve our final evaluation for these elements of the depiction itself. Free of a strict binding to the content of the work, we evaluate his choices, including among others the paper he uses, the layout 
of the photographs, their order in the sequence, and the like.

Ruscha anticipates an entire genre of photographic documentation, pioneered by the German couple Bernd and Hilda Becher. In the Bechers' work, the seriality and detachment that characterize Ruscha surge to the forefront. Most often deploying a $3 \times 3$ grid of large-format black and white photographs, the Bechers document coal tipples, grain elevators, mineshafts, hot-blast furnaces, and other totems of an industrialized wasteland. Their students, among them Thomas Struth, Thomas Ruff, and Andreas Gursky, have advanced their seemingly objective stance and, by digitally manipulating the images captured by the supposedly "neutral" frame of the camera lens, have elevated photography to a status close to that of painting.

But again, why? Whylook? Why should a set of nine photographs of coal tipples become an art object?

Well, why not? I am reminded now of "Saying \#77" from the "Gospel of Thomas," one of over fifty Gnostic texts found in 1945 in an urn buried in the sands of the Egyptian desert. Jesus: "Lift up the stone, and you will find me there."

There, even under some errant rock. It is probably not so hard for a Roman Catholic petitioner to feel the glory and majesty of her faith when she first steps into the marble-clad nave of St. Peter's basillica. It might be somewhat more difficult to find that sense of engagement and awareness amid the vast stretch of asphalt and glimmering bodies of SUVs in the parking lot of the local WalMart. But for many of us, the expanse of asphalt and the shoddy building at its flank constitute the bulk of our environmental experience.

Ultimately, you have to be where you are. You might as well look. You never know what you might find.

\section{Notes}

1. Thomas Merton quoted in The Little Zen Companion by David Schiller. New York, NY: Workman Publishing Co, 1994, p. 11

2. Sontag, Susan, "Notes on Camp," from The Susan Sontag Reader. New York, NY: Farrar Straus, Giroux, 1982, p. 112

3. Burns, Carol, "The Gehry Phenomenon," from Thinking the Present. 1990: New York, NY, Princeton Architectural Press, page 74.

4. ibid, p. 86 .

5. ibid, pps. 86-87

6. The Gospel of Thomas 77 from a translation by Marvin Meyer (adapted by Elaine Pagels) in Beyond Belief: The Secret Gospel of Thomas by Elaine Pagels. New York, NY: Random House, 2003, p. 238.

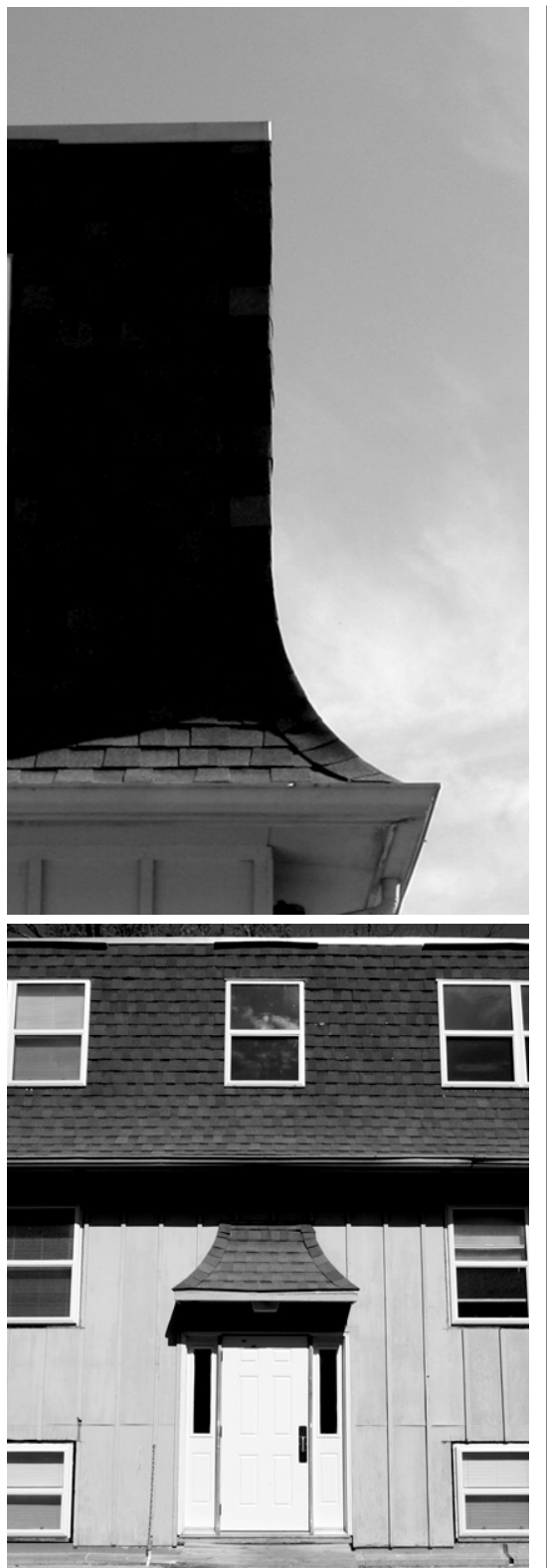

\section{Acknowledgements}

Students enrolled in Spring 2007 architecture seminar, "Some Manhattan Apartments": B. Elvis Achelpohl, Alexander Bley, Patrick Carpenter, Casey Culbertson, Michael Friebele, Chris $\mathrm{Kr}$ umrei, Nicholas Lamphear, Kyle Leiker, Grant McGill, Garrett Peace, Ian Schmidt. Corey Schneider, Breanne Vincent.

Top Hats photographs by Nicholas Lamphear, Kyle Landon Leiker and Grant McGill. Top Hats layout by Corey Schneider, from a scheme by Nicholas Lamphear and Grant McGill reflecting the buildings' locations within the Manhattan grid. The term "Top Hats" was coined by Nicholas Lamphear and Grant McGill.

Figure 1 photograph courtesy Raymond Streeter Figure 2 photograph courtesy Gustavo Ramirez. The author thanks all the above for their contributions. Dr. David Seamon provided valuable editorial guidance.
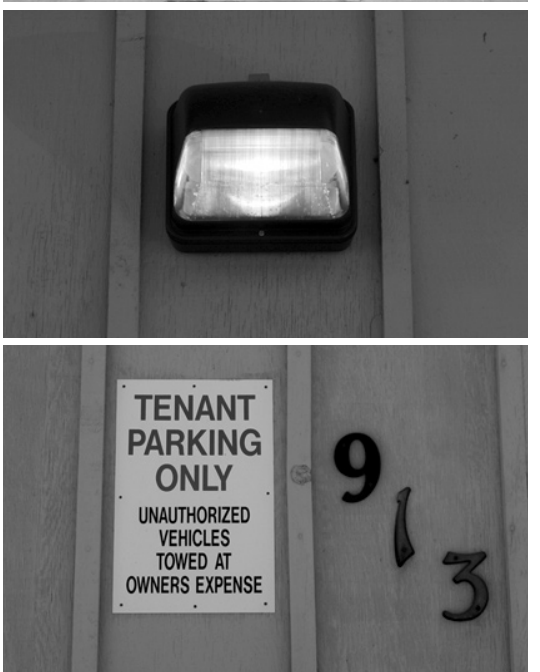

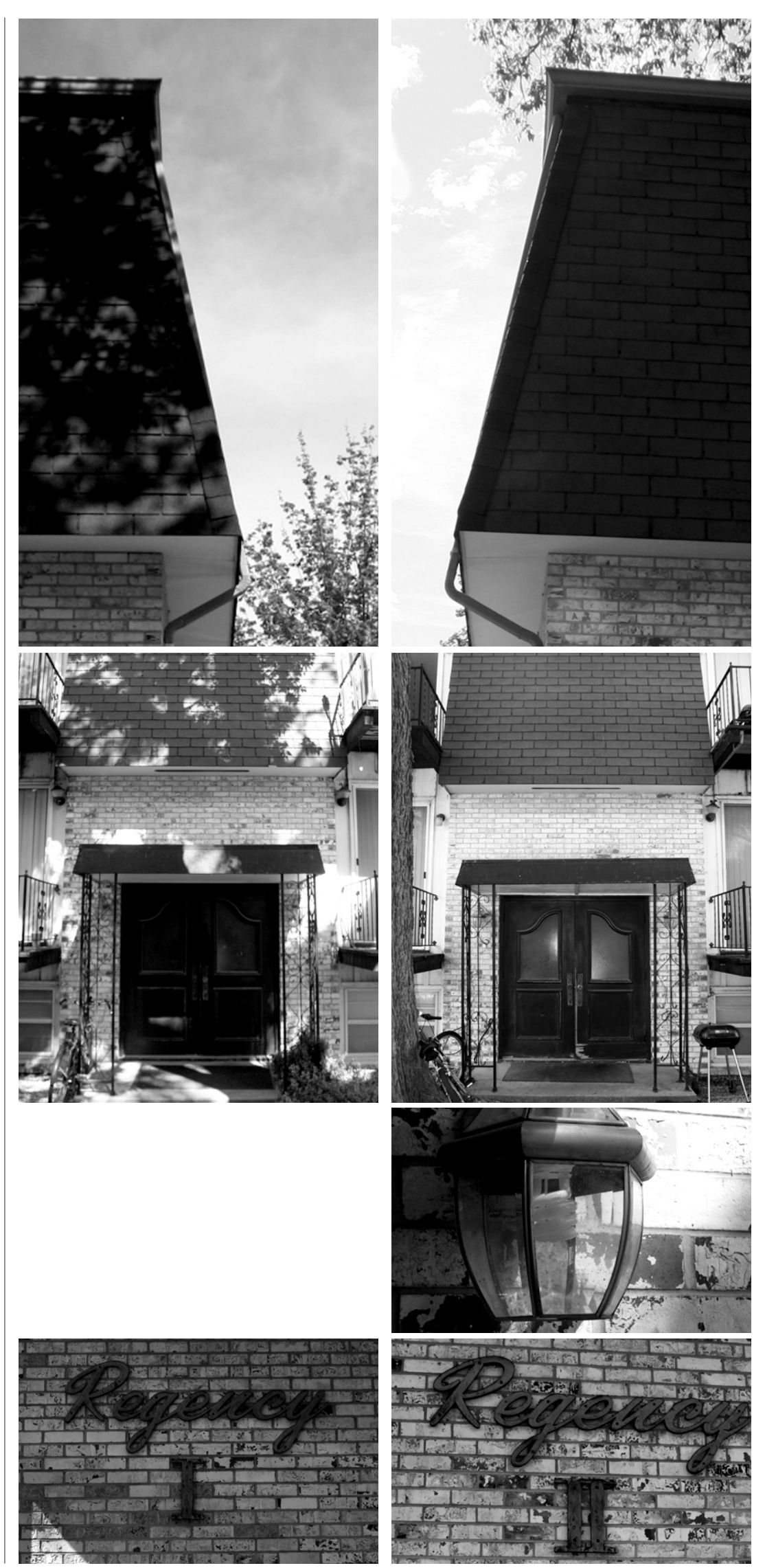

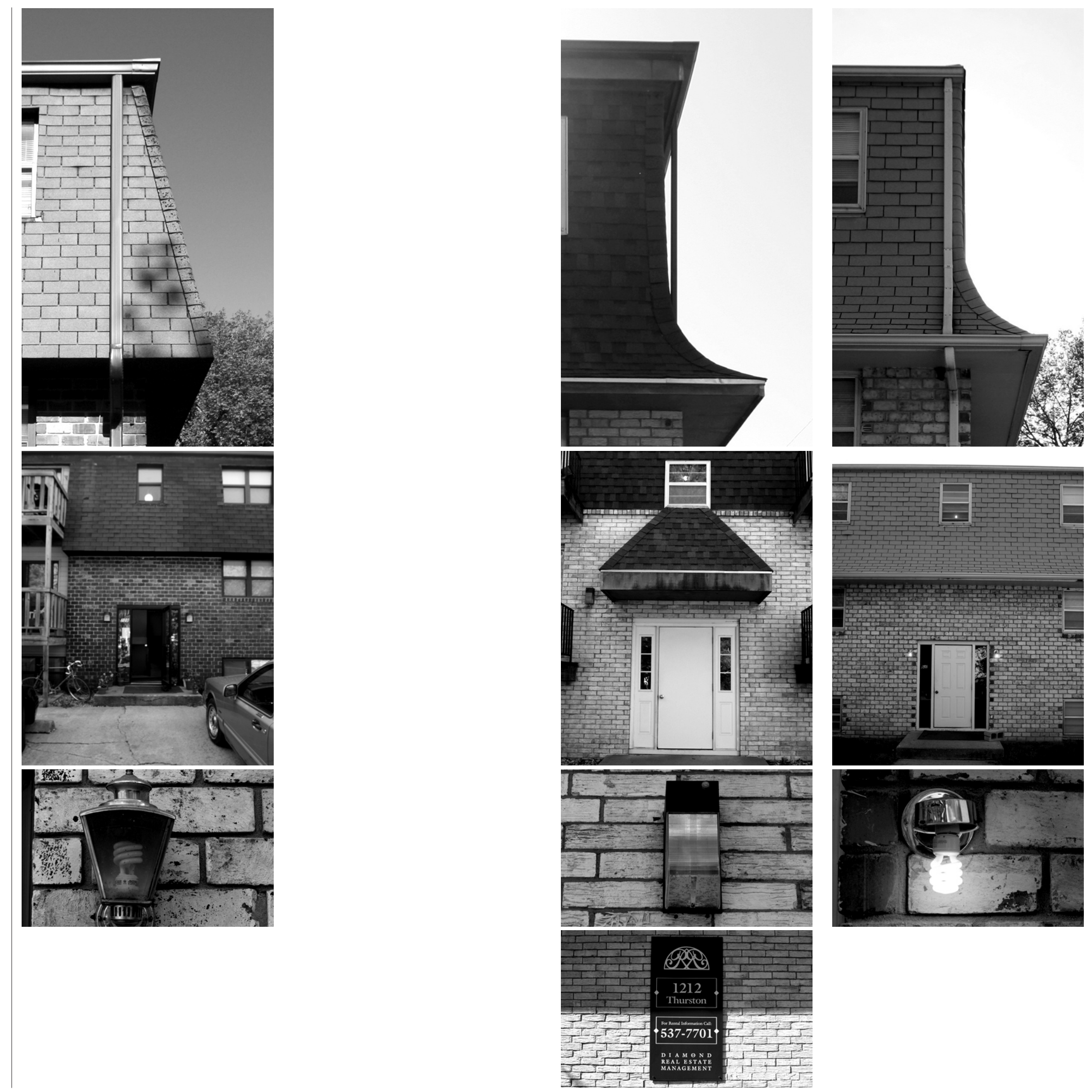

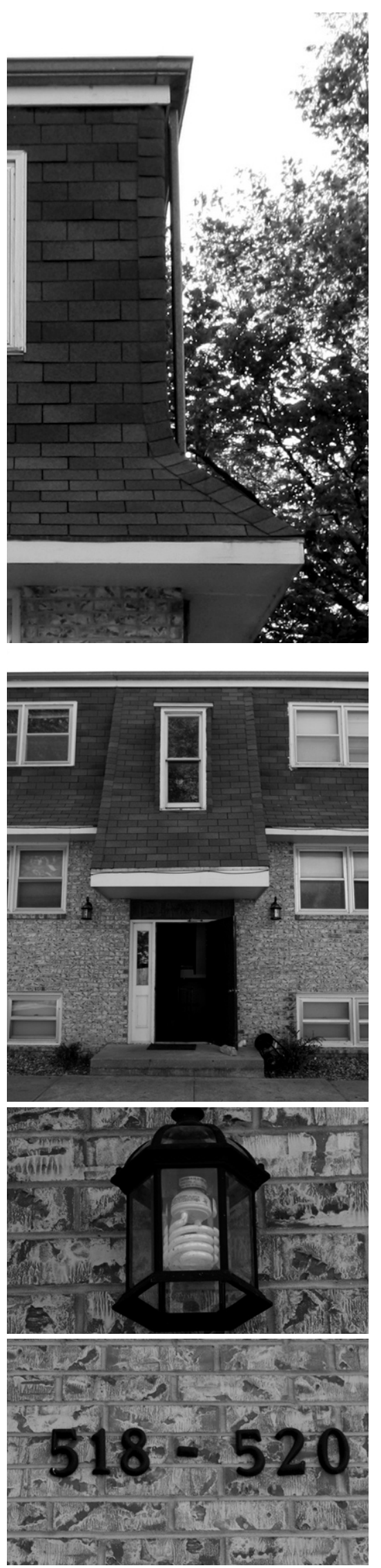

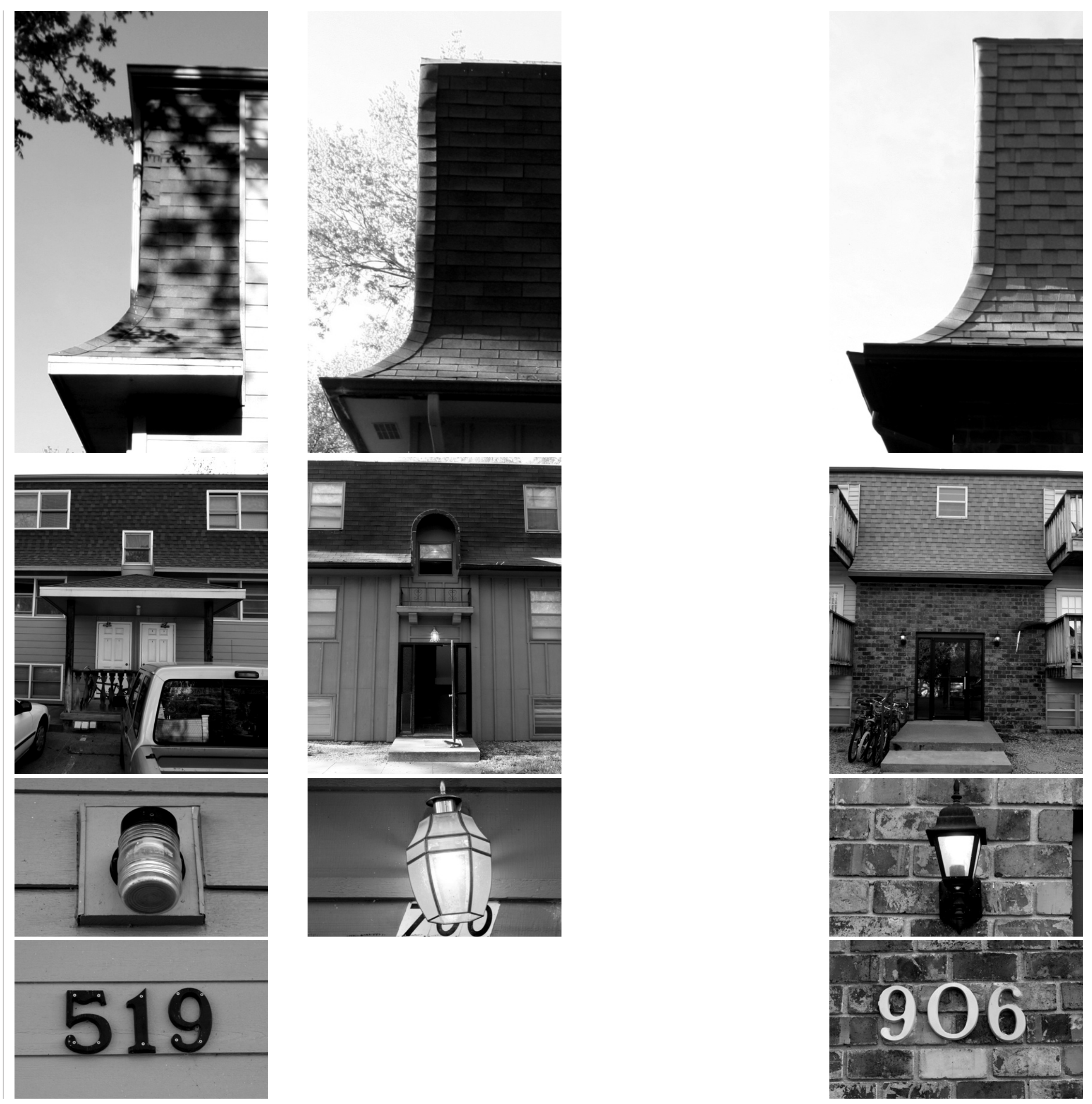

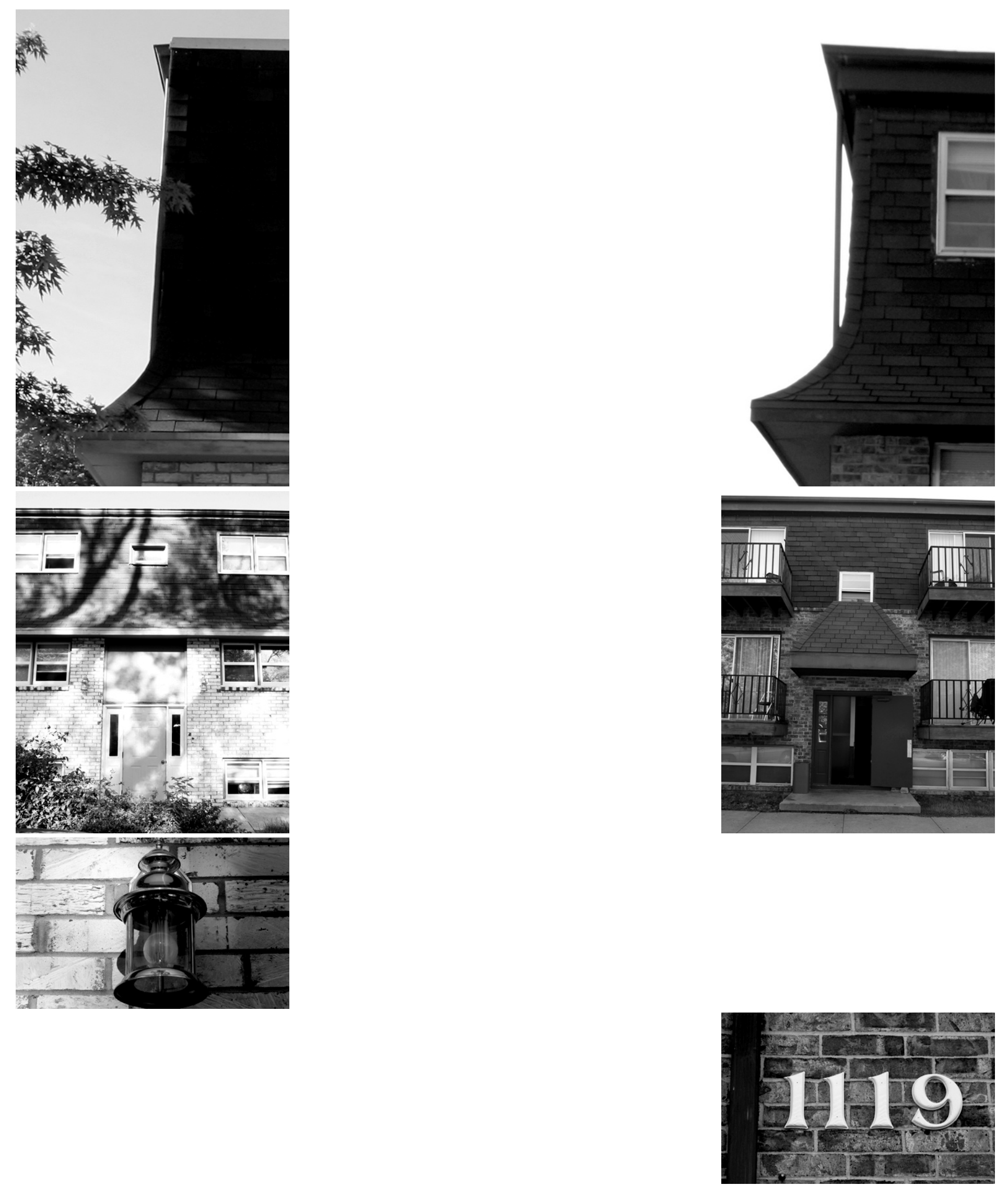

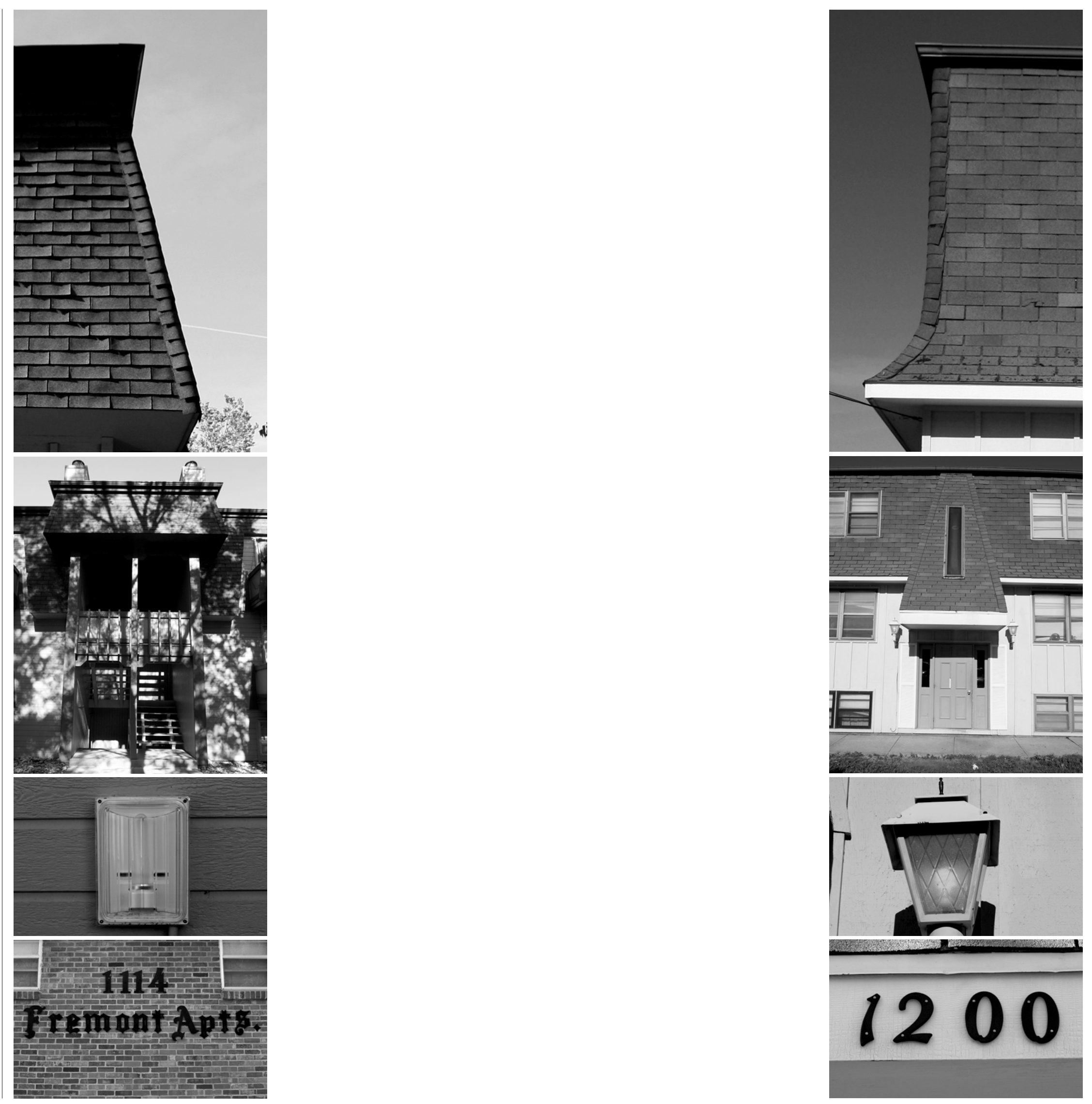